TITLE:

\title{
Higher education cooperation in ASEAN: building towards integration or manufacturing consent?
}

\author{
$\operatorname{AUTHOR}(\mathrm{S})$ :
}

Feuer, Hart N.; Hornidge, Anna-Katharina

\section{CITATION:}

Feuer, Hart N.... [et al]. Higher education cooperation in ASEAN: building towards integration or manufacturing consent?. Comparative Education 2015, 51(3): 327-352

\section{ISSUE DATE:}

2015-05-15

URL:

http://hdl.handle.net/2433/202835

\section{RIGHT:}

This is an Accepted Manuscript of an article published by Taylor \& Francis in 'Comparative Education' on 15 May 2015, available online: http://www.tandfonline.com/10.1080/03050068.2015.1031474.; The full-text file will be made open to the public on 15 May 2016 in accordance with publisher's 'Terms and Conditions for Self-Archiving'.; This is not the published version. Please cite only the published version.; この論文は出版社版でありません。引用の際には出版社版 をご確認ご利用ください。 


\title{
Higher Education Cooperation in ASEAN: Building Towards Integration or Manufacturing Consent?
}

\author{
Feuer, Hart N.*, Hornidge, Anna-Katharina
}

\begin{abstract}
The triad of cooperation, international exchange and integration among institutions of higher education has become the new norm in the global experience of learning and academic training. The goal of improving and standardizing the academic experience across countries is now typically also associated with fostering cultural and political ties and complementing processes of cultural integration, economic growth. Behind the rhetoric of many new initiatives, however, is a competition of geopolitical proportions, in which various national or regional systems of higher education try to shore up their positions or conquer new territory. In this paper we assess these discursive and material battles over institutional hegemony in Southeast Asian higher education by drawing on the sociology of knowledge approach to discourse. We critically address the competitive negotiation over higher education taking place between international and Southeast Asian educational players, asking whether these contribute more to integration than reinforcing dominant higher education domains.
\end{abstract}

Keywords: higher education, Southeast Asia, ASEAN, knowledge, regional integration

*Corresponding author. Email: hfeuer@gmail.com

Hart N. Feuer is a Senior Research Fellow at the Center for Khmer Studies (CKS), Cambodia and an Associated Researcher at the Center for Development Studies (ZEF), University of Bonn. His work focuses on higher education reform and internationalization, as well as on the sociology of food, with focus on food education and ecological agriculture. Email: hfeuer@gmail.com

Anna-Katharina Hornidge is a Professor of social sciences at the Leibniz Center for Tropical Marine Ecology (ZMT) and the University of Bremen, Germany. Before that, Ms. Hornidge was the Director and Professor of the Department of Social and Cultural Change, Center for Development Research (ZEF), University of Bonn, Germany. Email: hornidge@zmt-bremen.de 


\section{H.N. Feuer and A.-K. Hornidge}

\section{Higher Education Cooperation: Cultural and Political Integration or}

\section{Smokescreen?}

Cooperation, international exchange and integration among institutions of higher education have become the new norm in the global experience of learning and academic training. In the light of its role in various international relations, educational cooperation has moved beyond the national and bilateral levels and is increasingly becoming platform for regional and international agenda setting (World Bank 2000). The broader goals of this agenda, however, are not limited to improving and standardizing the academic experience but typically now extend to fostering cultural and political ties and complementing processes of cultural integration, development and peacebuilding. In this sense, higher education is increasingly viewed as an arena in which ideas about reconciliation of cultures and peoples are incubated and implemented. Behind this type of rhetoric, however, lies a conflict of geopolitical proportions, in which various national or regional systems of higher education try to shore up their positions or conquer new territory in order to maintain financial and academic competitiveness. In this sense, cooperation initiatives can also be viewed as platforms of negotiation for institutional hegemony over global higher education. The result of these machinations is that the hoped-for byproducts of international education integration, such as cultural development, economic growth and peacebuilding are contingent upon their instrumental value in facilitating the spread of various national or regional domains of higher education.

This 'cold war of higher education' is hardly a new phenomenon. The U.S. government used its political leverage in the 1950 s to promote elements of its university system in East Asia and Europe (Altbach 1973, 9-20; de Wit 2002, 16ff.; Huang 2007). West Germany instrumentalized higher education reform in the post-reunification era to facilitate the social integration of East Germany (Boatcã 2012). Western powers have used higher education as 


\section{H.N. Feuer and A.-K. Hornidge}

an ideological entry point into post-Soviet countries (Naidoo 2011). Elite universities from the USA, United Kingdom and Australia are busily vying to establish international branch campuses in foreign countries (Lane 2011; Wilkins and Huisman 2012). The expansion of the European Higher Education Area (EHEA), under the aegis of the 'external dimension' of the current Bologna Process, is a recent expression of an inherently competitive basis of higher education reform.

In part, expanding one country or region's educational system and the associated institutions into another country or region has a very practical orientation: it makes the degrees, standards, and languages of one higher education domain more widely accepted, and it facilitates academic and labor exchange and mobility. It also invariably has a socio-political orientation, becoming a struggle over different visions of 'knowledge' and 'knowledge creation'. Insofar as various schools of thought, political orientations, and economic systems are embedded in the mechanisms of various higher education domains, integration leads to legitimation and global tie-in to that domain's education ideology, market and academic corpus. This dynamic has invariably invited claims about the hegemonic orientation of higher education integration by a number of academics (see Figueroa 2010; Hartmann 2008; Naidoo 2011; Robertson 2008), whereby capturing or absorbing territory facilitates extraction of feepaying students, skilled workers, and high-level academics, as well as the impact scores and international reputation they bring with them.

In this formulation, higher education expansion is somewhat akin to Wallerstein's 'World Systems Theory', in which 'cores' (or domains, in our parlance) ${ }^{1}$ strategically win over semi-

\footnotetext{
${ }^{1}$ An alternative term, which is perhaps less useful for describing decentralized regional higher education systems like the USA, is 'polity' (see the example of Europe in Beerkens 2014, 5).
} 


\section{H.N. Feuer and A.-K. Hornidge}

periphery strongholds and periphery outposts in order to bolster the core system (Robertson and Keeling 2008). Even if one is not ready to accept this grand theory as applied to education, one has to question the altruistic intentions of various nations, regions, and consortia embarking on the international journey of higher education integration. To that end, in this paper we assess these discursive battles over institutional hegemony in the field of higher education by drawing on the sociology of knowledge approach to discourse (SKAD), developed by Reiner Keller (2005; 2011a; 2011b). Specifically we address how the practices of higher education integration are adjudicated in the rapidly-advancing region of Southeast Asia by looking at three 'lines of confrontation' that include (a) dominant international players (i.e. the EU, USA and Australia), (b) dominant regional players (i.e. Singapore, Malaysia, and supranational agencies), and (c) vulnerable regional players (i.e. Myanmar and Cambodia). In looking at these practices, we maintain that hegemonic predilections of higher education integration can and should be assessed not only as an avenue for critique, but also as a way to uncover the potential synergies between international competition and the fulfillment of various higher-order goals, such as cultural exchange, academic excellence, and peacebuilding.

To preliminarily answer this question, one has only to look at the increasing role of higher education as an arbiter of diplomacy, social integration, and conflict reconciliation. National, regional and international programs aimed at fostering international exchange have witnessed a steady increase in support in the past two decades by making light of these goals. The continuing unification of the European higher education system under the Bologna Process is a recent example of a regional effort to not only level the playing field dominated by U.S. education standards (Boatcã 2012; Hartmann 2008), but also to facilitate and encourage intercultural contact and mobility within and beyond European Union member states (Slantcheva-Durst 2010). It has also set the stage for European universities and institutes of 
H.N. Feuer and A.-K. Hornidge

higher education to more assertively expand their domain of engagement outside of Europe (ACA 2005). Discursively, this has emerged from a series of 'crisis narratives', which had suggested that European higher education was falling behind (European Commission 2001; European Commission 2005a; Robertson and Keeling 2008). This led to the inevitable conclusion that European countries needed to redouble and unify their efforts. Other policy domains of higher education have gradually taken note of the new assertiveness of the European Bologna process, with the USA (Douglass 2006; Goodwin and Nacht 2009; Margaret Spelling, US Secretary of State, quoted in Hartmann 2008, 212) and Australia (DEST 2006) producing 'crisis' narratives of their own to justify better coordinated responses.

Although this response plays out differently in each domain, actors from the various strata of the university, professional, and policymaking levels have come to more strategically value the overall competitiveness of their respective domains. Regardless of the degree of educational consolidation in Europe, Australia or the USA, regions such as Southeast Asia are being increasingly engaged through channels provided by embassies, academic exchange services and development agencies. While it is tempting to fall into methodological nationalism when observing this 'tooling up' (Aufrüsten) for global competition, it is worth noting that the nation-state (i.e. various governments) is actually devolving as the core actor (and therefore as the main unit of analysis) (Shahjahan and Kezar 2013), leaving a wideropen arena of contestation for players such as universities, consortia, multi-lateral quality assurance agencies, and regional blocs. In particular, trans-regional partnerships, bilateral cooperation, and university-level exchange are becoming more common (ACCESS 2010). With the increasingly consolidated EHEA representing the newest entry into the fray, it becomes clear that this is already a terrain crowded by other education domains that are not eager to give up their territorial claims. Since the actors involved in higher integration vary by region, we will revisit the characteristics of the dominant players after setting the stage in 


\section{H.N. Feuer and A.-K. Hornidge}

Southeast Asia.

In this article, empirical data from Southeast Asia is drawn from fieldwork conducted in the mainland in 2012-2013 (Myanmar, Cambodia, Thailand, Malaysia) and the islands (Singapore, Indonesia) in 2005 as well as 2006-08, and includes government and organizational programming material, agenda setting meetings and reports, documentations of negotiations, (web-accessible) process documentations, and interviews with officials and everyday people.

\section{The Contested Knowledge Society: The Emergent Higher Education Discourse}

In order to begin excavating the overlying trends and underlying discourses behind contemporary higher education reform in Southeast Asia, we draw on Reiner Keller's sociology of knowledge approach to discourse (Keller 2011a; Keller 2011b; Keller 2013). Already a number of papers in this field have looked at 'institutional discourses and the school as a place of discursive practice' (Keller 2013, 65). These papers have variously taken on methodological concerns (Rogers 2011), historical-evolutionary views on education (Ricken 2006) and the question of internal learning or the dynamic of reflexivity in education (Wrana 2006). The analysis in this paper puts a wrapper around a number of these works, extending the subject area to a living debate.

SKAD aims to examine 'the discursive construction of symbolic orders' constitutive in processes of social, discursive and communicative constructions of reality. It does so by studying the interaction and continuous shaping of diverse (potentially overlapping, mutually strengthening or conflicting) conceptualizations and the resulting politics of knowledge (Keller 2011b, 48). Discourses are thus regarded as 'the identifiable ensembles of cognitive and normative devices' (Keller 2005, 7), which communicate, legitimate, objectify and 
H.N. Feuer and A.-K. Hornidge

socially construct platforms of meaning with social consequences on the institutional, organizational and social actors' levels.

Keller therefore emphasizes the study of discourses as knowledge/power complexes that 'exist' both through and in 'practice(s)' and 'dispositifs'. 'Practices' are broadly defined as conventionalized patterns of action, based on collective stocks of knowledge about the 'proper' way of acting. Yet, in more detail, a distinction is made between discursive practices and non-discursive practices constituting the social processing of discourses, as well as model practices (i.e. templates for action) constituted in discourses for the respective addressees (Keller 2011a, 255-257; Keller 2011b, 55). 'Dispositifs' are defined as infrastructure established by social actors in order to solve a particular situation, with the more detailed distinction made between 'dispositifs of discourse production' and 'dispositifs from a discourse'. With regard to the relationship between discourse (as structure) and singular discursive events and practices, Keller refers to Giddens' 'duality of structure' (1992) and the mutually reinforcing relationship between social practices and the structures in place. He suggests that discourse as structure offers (a) normative orientations and rules for saying things; (b) rules of attesting to the constitution of meaning; and (c) social and material resources for action (Keller 2005, 6).

In this paper, SKAD guides analysis with regard to (a) the socio-historic embeddings of the higher education and integration discourses as well as the local rationales of ASEAN member countries for subscribing to them; (b) the construction of higher education integration as social imaginary for a better future; (c) the social and material resources for action mobilized with the aim to foster integration; and (d) some of the (un-)intended power effects. To this end, we focus on the actors determined by and determining the discourse of higher education integration as well as on discursive, non-discursive and model practices. The empirical 


\section{H.N. Feuer and A.-K. Hornidge}

sources we analyzed, which are listed above, include both official and unofficial texts, oral material, and other analyses. The different actors and their practices emerging from these resources, and thus the discourse on higher education integration itself, are in consequence assessed as 'performative statement practices which constitute reality orders and also produce power effects in a conflict-ridden network of social actors' (Keller 2011b, 48).

\section{ASEAN: The New Knowledge Battleground}

Many of the same pressures driving the Bologna Process in Europe are being faced in the regional bloc of the Association of Southeast Asian Nations (ASEAN), making it a dynamic and competitive area for higher education reform. Having already bought into the Westernoriented 'knowledge society' discourses underlying the Bologna Process since at least the 1990 's aim to ostensibly improve the quality of tertiary education through standardization and by encouraging mobility and inter-cultural exchange (Carter et al. 2011), the disparate initiatives in higher education integration in ASEAN have already invested in the relevant dispositifs in the form of consortia and quality assurance mechanisms. Although lacking an overall banner such as Bologna, such dispositifs underlie several initiatives to expand regional higher education cooperation, most notably cooperation and quality assurance networks such as AUN, AQAN, or SEAMEO-RIHED ${ }^{2}$. It is this ongoing internal education integration process that makes the 10-country bloc so attractive for higher education domains from the outside. Indeed, it is largely a region yet to identify a dominant higher education model but one that is, nonetheless, pushing swiftly toward economic and political integration. Getting a foothold in ASEAN would make almost $9 \%$ of the world population from a rapidly

\footnotetext{
${ }^{2}$ AUN: ASEAN University Network. AQAN: ASEAN Quality Assurance Network. SEAMEORIHED: Southeast Asian Ministers of Education Organization - Regional Institute of Higher Education and Development
} 


\section{H.N. Feuer and A.-K. Hornidge}

developing region into potential students, faculty, and cultural diplomats for an existing education domain like the EHEA, the USA or Australia. However, in order to maintain or establish symbolic order over education in a region like ASEAN that is undergoing a more general process of integration, external parties have to simultaneously tie the dominant dispositif of internal (economic) integration to 'external' (higher education) integration while fending off competitors.

Education exchange, mobility, and other types of international programs are already in progress, both in a decentralized way and through some formal channels. Cooperation between Asia and Europe is already picking up through programs such as AUNP, ACCESS ${ }^{3}$, Asia-Link and the Erasmus Mundus program. Variously, the USA and Australia have established and continued cooperation and cultivation programs such as APRU, ACODE, $\mathrm{UMAP}^{4}$, and the ASEAN Youth Volunteer Program. These programs support inter-regional and international mobility and international accreditation, and often form direct institutional links between various academic domains and target areas. However, like all forms of (development) intervention, higher education integration as a technical endeavor is subsidiary to national and regional politics and social issues. Indeed, Hornidge (2013, 409-410) referred to these as '(un-)intended power effects' implicit in the model dispositifs of the major education domains. Although the programs listed above nominally avoid questions of political economy and internal conflicts in ASEAN, these questions are not only lurking in the background, they may also represent certain opportunities for added engagement and thereby further expansion of power.

\footnotetext{
${ }^{3}$ AUNP: ASEAN - EU University Network Programme. ACCESS: Academic Cooperation EuropeSoutheast Asia Project

${ }^{4}$ APRU: Association of Pacific Rim Universities; ACODE: Australasian Council on Open, Distance and e-Learning; UMAP: University Mobility in Asia and the Pacific
} 
H.N. Feuer and A.-K. Hornidge

While ASEAN faces challenges in the same vein as that of the continuing Bologna Process, namely the integration of higher education in countries with high diversity, most notably in culture, language, and legacy systems of university education (Iskandar 2009; Selvaratnam and Gopinathan 1984), Southeast Asia faces other challenges and opportunities: (1) resolving drawn-out violent conflict in a number of sub-regions, and (2) overcoming the extreme differences in economic prosperity and social development between member countries. This is a region that includes both discordant and economically disadvantaged countries like Myanmar and Cambodia, as well as stable economic powerhouses like Singapore and Malaysia. Because of these differences, it is inevitable that external higher education domains adapt their discourses and practice to the unique situation of each country. To this end, external higher education domains, much like development agencies, are looking for strategic points of entry to higher education at both the regional and national levels. One emerging entry point for a number of ASEAN countries is the arena of conflict resolution (Feuer, Hornidge, and Schetter 2013).

For Southeast Asia managing existing or residual violent conflicts, higher education integration raises the question of how comprehensively these and other initiatives, and their regional counterparts facilitate cultural tolerance, integration, and peaceful coexistence (Selvaratnam and Gopinathan 1984). This type of international cooperation has the potential to help overcome obstacles in the integration process arising from human security and persisting conflicts within and between member states (Kuroda, Yuki, and Kang 2011). One assumption underlying this paper is that the regional and international platform of higher education reform is understood as much more than its impact on education quality, extending to questions of cultural understanding regional stability, but also to power relations between the member-countries of ASEAN. Since many of the conflicts within member states of ASEAN derive fundamentally from social and identity politics (Smith 2010; UNESCO 2011; 
H.N. Feuer and A.-K. Hornidge

World Bank 2005), the challenge at hand would be to find the right balance between promoting the parallel discourses of standardization and international exchange while not disrupting practices that undergird diversity in cultural expression and local governance. Some commentators (such as Beerkens 2008; Beech 2011) are generally more optimistic about this, noting the relative agency of many countries in adapting global models to suit local needs, while others are more pessimistic (see Figueroa 2010; Takayama 2014), understanding the practice of assembling integrated 'knowledge societies' as overly hegemonic. At least discursively, the disparate processes underway in higher education reform in Southeast Asia are aware of this challenge and offer a few pilot programs, but have not institutionalized or conceptualized their agency. In this paper, we address various ways in which both economically powerful countries and weak ones actively steer reform processes and passively exert agency in the context of external intervention.

As an arena for internal and external higher education integration, it is as important for various education domains like the EHEA, the USA and Australia to facilitate harmonious integration through their programs in Southeast Asia as it is for ASEAN member states. In a European consulting document unabashedly titled 'Strategies to strengthen collaboration in Higher Education between Europe and South East Asia', this strategy is outlined as follows:

\footnotetext{
'The significant differences among SEA countries, also in terms of Higher Education systems, should not be underestimated and the difficulties encountered in the Regional and sub-Regional integration processes are a clear indicator of the complexity of the task; but waiting for "regional integration" to be accomplished before accelerating the international integration process might reveal to be a losing strategy: the two processes should progress in parallel' (ACCESS 2010)
}

Here, proceeding 'in parallel' does not mean that international integration is necessarily discrete from regional integration. Within ASEAN, the early concerns have been to align the educational system of each member state to support the ongoing regional integration, which 
H.N. Feuer and A.-K. Hornidge

is mainly driven by economic processes (Beerkens 2004). For international actors, 'integration' becomes a discursive arena, in which external intervention in the symbolic order of power in Southeast Asia is encouraged and legitimized. In practice, economically stronger partners have the upper hand in the social processing of these discourses and negotiations, while weaker economies may have their own agency in regards to buy-in or hybridization of these various practices. The fault lines in this debate, unsurprisingly, become apparent in regional higher education meetings. As one Cambodian official confidently remarked to the author in a 2013 higher education integration conference,

'There is no doubt that the Singaporean and Malaysian higher education representatives are the strongest players in the meetings. But the Thai are also strong now; since they have similar concerns as us, we can cooperate together to have legitimacy in mainland Southeast Asia too.' (Anonymous 2013b, translated by author)

Indeed, even as bilateral tensions between Thailand and Cambodia were simmering due to a pending ruling from the International Court of Justice about a sensitive border dispute (Preah Vihear temple), Thailand and Cambodia tended to view themselves as natural allies in the interest of the mainland. The discursive bundling of higher education cooperation with political power suggests that certain countries already have a broadly strategic orientation toward protecting national interests in the regional platform. International players form an additional layer in this debate. A higher education official from Myanmar, speaking on the occasion of a European Commission-sponsored higher education integration event, raised this question of sovereignty:

'I agree that we need to catch up with the standards. But is there space to have our own standards?' (Anonymous 2013a)

In Southeast Asia, the poorer countries are often lumped together with the acronym CLM or 
H.N. Feuer and A.-K. Hornidge

CLMV (Cambodia, Laos, Myanmar, Vietnam), ${ }^{5}$ which represent countries that receive extra support from the Asian Development Bank. While this makes them eligible for financial assistance, being on this list is something of a moniker. Acknowledging the alienating effect of explicitly defining potential partners in this way, higher education functionaries in fields (such as quality assurance) dominated by relatively advantaged countries, have expressed the need to (nominally) adopt a more bottom-up approach (Fahmi 2013). Often the message is bordering on patronizing, as with one Singaporean official suggesting the need to

'establish QA [quality assurance] systems to leverage the quality of education management in CLM countries.' (K. C. Tan 2013)

Paying lip-service to the capacities of the economically weaker countries using such discursive practices is often part of the friendly dialogue in ASEAN-wide meetings, but does little to practically shift power relations or adjust the reigning 'knowledge society' dispositif put in motion by advantaged countries. Putting it more practically, a New Zealand professor of educational psychology stated at a higher education event in Cambodia,
'Notwithstanding the debate in regard to 'rote learning' in Asian countries, there has been a strong move towards teaching and learning practices that have been espoused by the Singaporean Ministry of Education, and that are practised in many Western countries, and increasingly in non-Western countries.' (Chapman 2013, XL)

Indeed, among other challenges, fundamental differences in the orientation and make-up of the knowledge society in each ASEAN-member country suggests that convergence will inevitably entail coercion and consensus building. We now turn to the nature of the dialogue in higher education integration, looking at the relative capacities and motivations of the actors at the international and regional levels.

\footnotetext{
${ }^{5}$ A less direct, but more polite form refers to the GMS countries (Greater Mekong Subregion).
} 
H.N. Feuer and A.-K. Hornidge

\section{Proselytizing Models: The International Domains of Higher Education}

As a sector embedded in a broader national or regional space, higher education systems are dependent on two factors outside of their direct sphere of control: competitiveness/attractiveness of the home country/region and legitimation of their degree system. As ambassadors representing the interest of their nation, region or domain, consortia and other bilateral and multilateral actors attempt to improve these terms. Succinctly put by Adelman $(2009,168)$, the imperative of the Bologna Process is in 'increasing the odds of cross-border labor market flow as a by-product of common qualification frameworks and recognition of degrees'. This characterization can be applied to other higher education domains, like the USA and Australia. We elected to use the term 'domain' (over policy area, system, polity, or sphere) because it connotes a type of state-society intervention over geographical territory while also existing as a supra-national form of (membership) organization. Domains can also overlap, which is to say that we accept that the competition for higher education dominance is not a zero-sum game (Hartmann 2008) and, indeed, can often accommodate or benefit from overlap of certain domains. In practice, higher education domains always overlap in terms of their representation (i.e. draw of students, presence in standard-setting) in each country or region, although this is governed to some degree by a global hierarchy of higher education systems (see Verbik and Lasanowski 2007). ${ }^{6}$ This will be illustrated in more detail in the descriptions of the domains below.

\footnotetext{
${ }^{6}$ They outline the following world hierarchy of higher education actors: (1) The Major Players: the United States, the United Kingdom and Australia; (2) The Middle Powers: Germany and France; (3) The Evolving Destinations: Japan, Canada and New Zealand; and (4) The Emerging Contenders: Malaysia, Singapore and China.
} 
H.N. Feuer and A.-K. Hornidge

\section{The European Higher Education Area}

With its renewed push for consolidation since the Lisbon Convention in 1997 and the formal beginning of the Bologna Process in 1999 (both model practices in Keller's understanding), European members have focused primarily on expansion, harmonization and mutual recognition of higher education degrees. Since its inception, 48 countries have officially joined the EHEA (see Figure 1, which is still up-to-date).

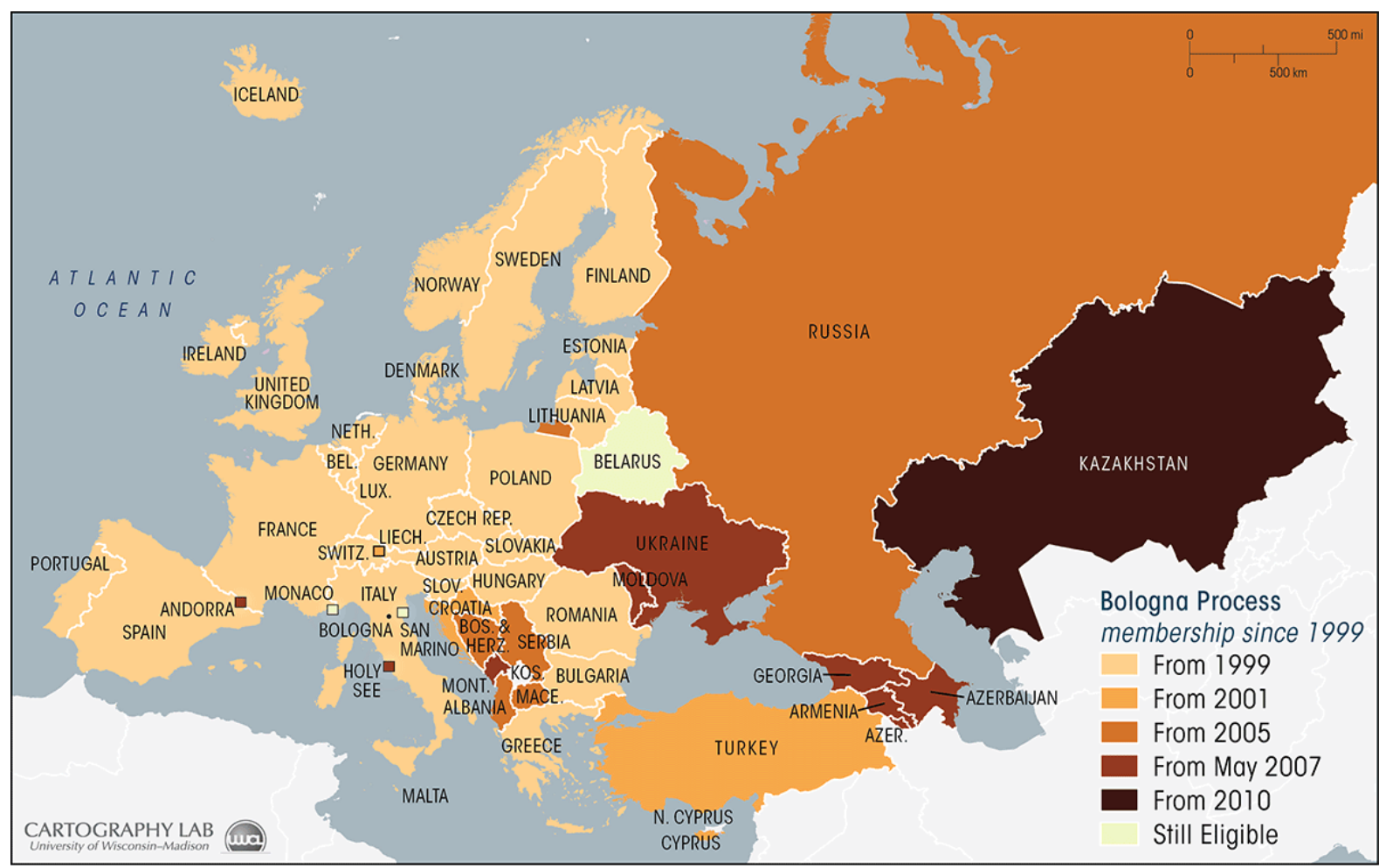

Figure 1. Bologna Process Membership. Source: Olds and Robertson (2011)

The rapid expansion in Western Europe can be understood as an extension of integration processes under the European Union, but the extension to Central and Eastern Europe and beyond is part of its more recent expansionary logic. Indeed, the Bologna Process should be seen as distinct from the EU, being aligned more officially with UNESCO under the Lisbon Convention (Hartmann 2008). This multilateral footing has helped add a global orientation to the original establishment of this new higher education area. The fact that Bologna has come to symbolize the outgrowth of a centralized model to satellite areas is, however, perhaps 
H.N. Feuer and A.-K. Hornidge

ironic, as the historical Bologna University model has historically been associated with 'control by students', or a very locally adapted approach to university governance (Altbach $1973,5)$.

Inscribed in the Bologna agenda in 2005, but informally acted upon beforehand, is the 'External Dimension', which elaborates and justifies the global engagement of the EHEA (see Zgaga 2006). The results have come quickly. The Catania Declaration of 2006 established a 'Euro-Mediterranean Higher Education Area', while the Asturias Declaration of 2006 (between the European University Association the Spain-based Consejo Universitario Iberoamericano) outlines Bologna-inspired reforms underway in Latin American and Caribbean higher education systems (EUA and CUIB 2006, 2). Various declarations have aligned, separately, Chile and Mexico with the Bologna Process (Figueroa 2010), as well as starting programs in Africa, North America, and Asia. Concrete regional integration with Southeast Asia, a bastion of American and Australian influence, is perhaps still too early to definitively conclude.

Indeed, Southeast Asia appears to be a region in which the higher education domains are predestined to lock heads. The European Commission $(2001,20)$ has acknowledged its need to raise the 'profile of Europe in Asia' now that the concept of Europe as a destination is more concrete under the EHEA. Despite the illusion of its unified front, or strong organizational dispositif, in the background is the reality that the EHEA is itself still long from being consolidated (Robertson 2008). As noted by an EU higher education representative to an ASEAN meeting,

'Notwithstanding the overall positive development, the European dimension of quality assurance is still limited. National regulations are still driving the majority of [quality assurance] agencies' activities.' (Lugano 2013) 
H.N. Feuer and A.-K. Hornidge

Despite this backlog in Europe, countries and regions around the world have pre-emptively began aligning with or incorporating some of the Bologna standards. The World Education Service (2005) (largely representing the USA) has acknowledged that the three-year (or occasionally four-year) bachelor's degree espoused in the Bologna agenda will be largely considered equivalent to U.S. bachelor's degree. Incorporation has also begun in competing education domains like the USA and Australia, where individual standards or institutions have aligned with Bologna. In the state of Utah and in a few universities in Australia, the Diploma Supplement component of the Bologna accreditation has been adopted (Adelman 2009, 169; Hartmann 2008). In other relationships, the pressure to adopt Bologna standards is driven by the practical need for access to well-funded higher education initiatives. For institutions participating in ERASMUS Mundus, the extra-European student exchange program, institutions have largely adopted (83\%) the EHEA's credit transfer system (ECTS) in order to facilitate implementation and funding (Maiworm 2006). In regions where Bologna is still being preliminarily set up, less coercive measures predominate. The Asia-Link program (mostly in Southeast Asia) does not demand alignment with the ECTS, but requires co-financing as a way of encouraging solid inter-institutional collaborations that more effectively anchor European partnerships (European Commission 2005b; Robertson 2008). Nonetheless, observers from certain regions have begun to comment about the passively coercive tendencies and unintended power effects of Bologna:

\footnotetext{
'This abstract 'space' of higher education symbolises the exportation of a European model through which others will come to understand, conceive, plan and organise the functional, structural and content dynamics of the universities outside of Europe.' (Figueroa 2010, 254)
}

And indeed, Croché and Charlier (2012) document how the policy flexibility still found in national higher education systems in Europe proper is often lost through reification when the 
H.N. Feuer and A.-K. Hornidge

Bologna standards are exported to other regions (in their case, Francophone Africa) but that the resulting simplicity makes education integration with Europe more transparent and accessible for policymakers grasping for concrete measures to take.

\section{The USA}

As the inheritor of the most dominant higher education system of the 20th Century (Altbach 1973), the first destination of students studying abroad (NAFSA 2014a), and still the home to some of the top universities in the world (Times Higher Education 2015), the USA has built up the strongest passive and active presence in higher education exchange and integration. After WWII, the USA was the first to develop a model of mass higher education and set up democratic institutions that were able to bring in new branches of knowledge faster. As a result, the USA basically became the paradigm in the 1970s, a position it exploited to expand its higher education domain abroad and bulwark its reputation:

'[the] major reason for the impact of American patterns of higher education overseas is America's political and economic power throughout the world. Not only is the U.S. a wealthy and technologically advanced nation, and therefore a natural model to other countries, but the large amount of foreign aid in terms of educational assistance and advice provided to developing countries by the U.S. is a very strong influence. American universities have been deeply involved in assisting institutions of higher education in other countries, and it is common that the models provided by American planners are similar to those found in the U.S.' (Altbach 1973, 9)

As noted by scholars examining the latent strategies in the Bologna process, the USA encouraged 'a global market in QA agencies [...] dominated by countries with wellestablished agencies such as the USA' (Hartmann 2008). And through the present, the USA has continually increased the amount it benefits from international students, totaling USD 26.8 billion in 2013-2014 as calculated by the U.S.-based Association of International Educators (NAFSA 2014b). However, the share of international students received by the 
H.N. Feuer and A.-K. Hornidge

USA has declined by 28\% between 2001 and 2012 (OECD 2014, 201) and the general tone in American university circles has become more somber since the heyday of the 1970s.

Due to its limited cohesiveness as an education 'polity', high cost and growing competition from other education domains, the U.S. has struggled to maintain its dominance in international education integration. Internal, self-critical pieces describing the decline in the American education system are no longer rare (Douglass 2006; NAFSA 2008), while reports describing how to respond to Bologna, and what the USA can learn from Bologna, are increasingly visible in academic policy circles (Adelman 2009). Over time, a decidedly inward orientation to accreditation may have limited the expansion of the American system (Altbach and de Wit 1995) while protecting the exclusivity of domestic universities. In summarizing a debate in which Philip Altbach refers to American accreditation as 'academic invasion' or 'academic colonialism', Brittingham (2003) argued that some accreditation abroad was necessary to stay competitive abroad, especially for outposts of American-style education. While some of the international branch campuses of American universities have done this, and standardized tests like the American Student Achievement Test (SAT) still hold sway, the incentive for accessing the European Register of quality assurance agencies is notably clearer: it requires parties to adopt European norms if they want to accredit universities under the Bologna aegis.

While on a practical level, it is the lower-tier universities in the USA that are beginning to struggle, and which will face the brunt of shifting priorities to Europe, Australia, or other regions. Their concerns have begun to take the wind out of critics who decry any losses to the uniqueness of the American system. 


\section{H.N. Feuer and A.-K. Hornidge}

\section{Australia}

As the 'local' educational powerhouse in Southeast Asia, Australia's internal student mobility has predominantly come from Asia (around 60\% through 2009) ${ }^{7}$, which makes it more reliant on its performance in maintaining and attracting student flows from the population-rich ASEAN countries. And contrary to the USA, Australia has reacted proactively to the increasing presence of Bologna activities in its geographic home turf although it ultimately elected not to align itself overly with European standards. As described by Adelman (2009, 171),

'In terms of student mobility, Australia is in the position of balancing gravitational pulls from Europe, the U.S. and the major Asia-Pacific higher education systems, and, like other systems outside of the Bologna universe, maintaining the integrity of its own enterprise and traditions.'

The original interest in aligning with Bologna came with a 2006 Working Paper from the Department of Education, Science and Technology (DEST), soliciting input about the extent to which the sector should adapt. As seen in those formative years,

'not only European but also non-European agencies have signalled their interest in being registered in Europe in order to ensure that their evaluation of a European study programme is accepted by the European countries, which in turn increases the value of their quality labels. Again the influence is most visible in Australia.' (Hartmann 2008)

While Australia feared losing the sizable student population from Europe, it also needed to maintain enough distinctiveness to retain its competitive edge with North American and Asian institutions. The reactions to the 2006 Working Paper were largely ambivalent to largescale adoption of Bologna, viewing Australia's already-dominant position as a competitive

\footnotetext{
${ }^{7}$ Based on statistics from the UNESCO Institute of Statistics: http://www.uis.unesco.org/
} 
H.N. Feuer and A.-K. Hornidge

market for students to be insulated from this threat (Donaghue 2008, 70). Indeed, Australia viewed Bologna as a marginal way of fixing ailing university systems rather than, as would be the case of Australia, reforming well-functioning ones. As a result, most of the critical elements in the Bologna process were rejected in subsequent discussions over higher education reform (Donaghue 2008, 65).

Even though adoption of Bologna was not widespread (it was mostly limited to taking up the Diploma Supplement and certain changes made at the University of Melbourne), it led to frantic comparisons indicating that the Australian system, modeled after the British, was not far from Bologna in most respects. In other words, Australia was interested in maintaining the existing perception about its unique system but eagerly wished to prove 'functional equivalence' in degree recognition so as not to threaten student flows from Europe. In the meantime, Australia redoubled efforts to consolidate its hold over regional standard setting in Asia-Pacific so as to ensure that other important flows from its core region were also not disrupted (Stella and APQN 2008).

\section{Strongholds and Outposts: Higher Education Agency in Southeast Asia}

Although smaller in scale and bearing less notoriety, a number of the more economically dominant countries in Southeast Asia are also in the process of expanding their higher education domains and strategically positioning themselves within the broader higher education hierarchy. Most notably, these include Singapore and Malaysia. For these countries, ASEAN economic and political integration is the key conduit for raising their profile and cementing their position as regional powerhouses. Standing to profit from tighter regional integration, Singapore and Malaysia have been most vocal and engaged in the everyday business of higher education integration. Their ideals are visible in communiqués from quality assurance agencies (largely dominated by them), such as: 
H.N. Feuer and A.-K. Hornidge

'If the countries do not reflect collectively now on what is good for regional development and agree on the regional approach, after a few years of un-coordinated development, maximizing the benefits of the various national initiatives for regional development will prove to be even more difficult.' (Stella and APQN 2008, 25)

By creating an imperative for higher education integration, they also position themselves as the most likely candidates to bring about, and fund, the regional coordination. But they must also compete with the global powerhouses, which often means making strategic alliances. Below, we describe the current situation and strategic considerations of these two players.

\section{Singapore and Malaysia}

Both inheritors of the British system of education, Singapore and Malaysia have made use of their relationship to England and membership in the Commonwealth, in addition to their economic growth, to advance and legitimize their higher education systems. While a one-toone comparison of Singapore and Malaysia might disadvantage Malaysia (Marginson 2011), among ASEAN countries, both are regional economic and political powerhouses in the context of higher education (Evers and Hornidge 2007; Hornidge 2007; Hornidge 2010; Hornidge 2011). Malaysia is the top country for transnational education (TNE) provision of UK qualifications in the world, with around 60,000 students (UK Trade \& Investment Malaysia 2013). Singapore, in comparison, is home to the highest-ranked university in Southeast Asia (the National University of Singapore) and is a high-demand destination for intra-regional student exchange. The 'Singapore Scholarship' program for funding international students from within the region, has been a particular success. ${ }^{8}$

\footnotetext{
${ }^{8}$ Under this program, Singapore opens all domestic scholarships to the outside (open eligibility), charges tuition for non-residents of only $10 \%$ above local, and offers favorable interest rates for student loans.
} 


\section{H.N. Feuer and A.-K. Hornidge}

Furthermore, Malaysia and Singapore are the regional leaders in quality assurance frameworks for the ASEAN platform, with professionals from both countries consistently making up a high proportion of the membership in regional quality assurance and accreditation agencies. ${ }^{9}$ Universities in both countries are also prominent members in regional higher education associations, such as the Association of Pacific Rim Universities (APRU), as well as international higher education associations, such as the International Alliance of Research Universities (IARU). Both countries use English as the dominant medium of instruction and in general, both countries can simultaneously be regarded as careful arbiters of external standards and internal drivers of regional standards.

These two countries differ in the ways in which they accommodate foreign higher education institutions. Singapore is highly international and management-driven, using programs like 'Global Schoolhouse' and 'Singapore Education' to bring foreign campuses to Singapore and setup world-class partnerships (Ka Ho Mok 2011). In this selection, however, Singapore is proactive and highly selective of international partners, particularly when one compares to lower-income Southeast Asian countries that are targeted by development interventions. In 2005, a Singaporean higher education leader outlined the long-term focus on ASEAN and the short-term goal of establishing international legitimacy:

'Regional cooperation is still far away. Of course ASEAN is trying to push it but ASEAN is still too divided and too diverse. So what will actually happen is education and research networks between cities worldwide.' (Paul, 2005) ${ }^{10}$

\footnotetext{
${ }^{9}$ Based on the authors' tabulation of available records from AUN, AQAN, and SEAMEO-RIHED.

${ }^{10}$ In 2005, Johnson Paul was the Deputy Director of Research Services and Publications of the Singapore National Library Board. By 2014, he was the Senior Associate Director at the Institute of South Asian Studies at the National University of Singapore.
} 


\section{H.N. Feuer and A.-K. Hornidge}

In Malaysia, national universities were granted statutory status, which enabled them to compete for outside funding but also forced them to prove to the state through their performance that they deserve internal funding. Unlike Singapore, Malaysia has struggled to attract and negotiate the same elite partnerships as Singapore. This has been blamed, variously, on the extent of bureaucratic oversight in Malaysia (which includes a separate Ministry of Higher Education), the requirement for foreign universities to incorporate as majority-Malaysian-owned companies, more complex linguistic criteria and curricular demands (Ka Ho Mok 2011). The result is that, while Singapore has positioned itself widely both extra-regionally and within ASEAN, Malaysia has remained primarily an outpost of the British education system and as a superior destination within the nascent ASEAN higher education area.

\section{Higher Education Reform and Standardization in ASEAN: A New Entry Point for Hegemony?}

In many of the significant regional events on the subject of higher education, there is an implicit consensus that wide-ranging higher education reform is necessary; these events are usually bundled together with workshops on standard-setting and quality assurance that take place in an atmosphere of apparent solidarity. Practically speaking, this seems to be a logical way forward - one which is espoused by external experts with superior university systems and presents itself as a no-brainer: after all, who doesn't want high(er) quality education? Even to skeptics, higher education reform appears to be an inevitable aspect of globalization that the region might as well benefit from. The ASEAN University Network's Quality Assurance program (AUN-QA) was initially recognized by ASEAN+3, which includes 


\section{H.N. Feuer and A.-K. Hornidge}

China, Japan and Korea. ${ }^{11}$ Financial support and training for the poorer CLMV countries were supported by the Japan-ASEAN Integration Fund (JAIF) (K. C. Tan 2013), giving these initiatives a 'development' veneer as well. As a result, higher education reform is discursively connected with regional integration, which is to be overseen in a de-politicized manner by external parties who can objectively guide and confirm the reforms. This is captured neatly in reports by regional monitors, such as the Asia-Pacific Quality Network (APQN):
'With due regard to diversities in the national contexts, the region should promote the policies and practices that are strong points of the region. However, it is not always clear which policies and practices should be promoted in the region. To steer the regional development in QA towards most valuable practices, there is a need to look at the external points of reference.' (Stella and APQN 2008)

Within three sentences, the report shifts away from respect for national systems to regional and to international (external) intervention. Navigating back and forth along this axis is a discursive strategy employed in many higher education reform documents and at many highlevel meetings, as it suits the needs of external parties very well. In a presentation by a German Academic Exchange Service (DAAD) representative to Myanmar on quality assurance, the following point was suggested:

'Enriching intra-regional dialogue and cooperation by 'European flavor': exchange with European experts and trainers' (Wilde 2013)

This single line embodies a number of the discursive contradictions in trying to simultaneously play the role of neutral observer and 'shaper' of political dialogue in a foreign region. By 'exchange', the representative implies that constellation of power relations within and outside of the region are equal, despite the fact that, by rule, 'experts and trainers' do not

\footnotetext{
${ }^{11}$ Specifically, the ASEAN Plus Three Senior Officials Meeting on Education (SOM-ED+3) and the ASEAN Plus Three Education Ministers Meeting (ASED+3)
} 
H.N. Feuer and A.-K. Hornidge

learn from their trainees. The verb 'enriching' might be read by some as 'hijacking intraregional dialogue'. The power relations between and outside the region are further glossed over with terms like 'harmonization', which suggests that compromises in regional policy and alignment with external standards are mostly technical, rather than political, questions.

If higher education reform becomes synonymous with standard setting, adoption of quality assurance frameworks becomes the medium by which higher education domains can exert their influence in third countries. What is good (preferred) for the region, the logic goes, will also be good for each member country in ASEAN:

'By using the lens of regional, comparative analysis, presentations from the UNESCO experts allowed participants to weigh options for policy reform in Myanmar by drawing on best practices and lessons learned from other ASEAN countries.' (UNESCO 2013)

Best practices from ASEAN were, in this case, extracted by a committee made up of experts from Hong Kong (1), Singapore (3), the UK (1), and the UNESCO Bangkok office (2). The region, in this case, is more-or-less a proxy for external policymakers and dominant players in the region who consistently buy into internationalization. If countries try to go it on their own (as Thailand had for the previous decades), and do not buy into the regional solidarity discourse, they can be criticized for not having leadership, as one regional document implies:

'there is a lack of leadership for respective countries to strengthen their national quality systems. Further collaboration on developing the regional quality assurance framework will address these issues.' (SEAMEO-RIHED 2012, 5)

In the rush to achieve meaningful economic integration by the self-imposed deadline of 2015 , many poorer ASEAN countries have been compelled to buy into the regional solution without much of a domestic debate, a position boldly called out as 'akin to modern slavery' by a Cambodian representative to an education forum in Nagoya, Japan (Seng 2014). To go 


\section{H.N. Feuer and A.-K. Hornidge}

further, we look at the case of Myanmar to illustrate some of the risks that this entails.

\section{Myanmar}

In a 2013 article, the New York Times described Myanmar's university rectors as 'reaching out' to the world (Farrar 2013) and highlighting the buzz of university partnerships being signed and the assistance flowing to Myanmar's higher education sector. Other observers would suggest that it is not Myanmar reaching out, but expansionist higher education sectors 'reaching in'. The Deputy Minister of Education of Myanmar, Myo Mint (2013), suggested that 'universities that want autonomy must seek their own funding', by which he implied create private/public partnerships. A commentator in the audience questioned whether this simply meant trading one slave master off for another, but was relieved to find out that universities usually deal with multiple external institutions, thus diluting dependency on any one source. Signing deals with every foreign entity that comes along may actually further autonomy, and perhaps allow resources and qualified staff to flow in, but it also threatens coherence and sovereignty over higher education policy.

The disarray that can be generated is evident in the new International Center of Excellence at Yangon University (YU), which preliminarily opened its doors in January, 2013. It is organized by a national NGO cooperating with John Hopkins University, but with additional funding from the Korean International Cooperation Agency (KOICA). In practice, Chung Ang University in Korea has provided the most direct logistical support. Later in 2013, the University of Cologne also signed an exchange partnership with them. At a similar time, the YU's anthropology department began collaborating with Hanyang University, Korea. The law department, together with the University of Nagoya, established the Japan Myanmar Legal Research Center. Additional memoranda of understanding have rapidly come in from the Australian National University, Thepsatri Rajabhat University (Thailand), Hankuk University 
H.N. Feuer and A.-K. Hornidge

(Korea), among others. Additionally, collaboration for an e-library with Cornell University started in 2013, sponsored by the Open Society Foundation (also known as the George Soros Foundation). At the time of writing, a consortium of American universities was receiving funding from USAID to set-up shop in Yangon as well.

The breathtaking speed and diversity of the organizations involved would be both exciting and bewildering to any university recovering from decades of neglect. The question to ask of these initiatives is whether they are driven by specific and outlined needs in Myanmar or whether they are 'supply-driven'. A quote in the New York Times article from Jacque Fremont, director of the international higher education program at the Open Society Foundation, suggests the latter:

'Many, many major international universities would like to have a piece of the pie.' (quoted in Farrar 2013)

The extent to which these partnerships are supply-driven can be understood when looking at the distribution of new higher education deals in Myanmar. While Mandalay University has begun cooperation with a number of French universities, in addition to their longstanding relationship to the University of Cologne (Kraas 2013), most partnerships are inked in Yangon, with YU (King 2013). Given the international concern over conflicts in less metropolitan areas of Myanmar, one would expect support to target some of the more than one-hundred universities outside of the capital's metropolitan area. This is largely not the case. And even the funding that is slated for increasing capacity and resources at YU is diluted by parallel funding for higher education fairs attempting to 'raise the profile' of university systems outside of Myanmar and Southeast Asia (ACA 2005). 


\section{H.N. Feuer and A.-K. Hornidge}

\section{Negotiating Higher Education Models: Integrationism and Conformism}

The scenario outlined above suggests that the economically weaker ASEAN countries will have no choice but to participate in the rapid regional and international higher education integration process. In light of the 2015 deadline for economic integration in ASEAN, this inevitability only becomes more pronounced (Feuer 2014). However, looking at the extent to which stakeholders connect higher education reform processes across ASEAN with national imperatives gives an idea about the way in which this discourse is being adapted from its originally western agenda. From this perspective, ASEAN has a decidedly regionalistculturalist orientation. A Malaysian higher education official noted that ASEAN needs to 'learn from the EU' while avoiding the emergent disputes in the EU (Fahmi 2013), and in doing so keeping a cautious distance from the Bologna Process. More stridently, faculty and high-level officials from Cambodia and Thailand's respective ministries of education have, in recognition of their fears about 2015, argued for a more sensitive approach. Bunlay Nith (2013a), the Deputy Director-General of Higher Education from Cambodia suggests the need for 'an ASEANization to combat the Americanization and Europeanization of education'. The round table that he participated in entitled 'ASEAN Education' at the International Conference on Educational Reform, held in Siem Reap, Cambodia, had a very regionalist orientation, with one participant from Thailand stressing that, 'everyone wants to be unique, ASEAN wants to be unique' (Kanyajananiyot 2013).

This response in ASEAN was predicted as far back as the 1980s by Selvaratnam and Gopinathan $(1984,78)$, who predicted the nature of the contestation between intra-regional and extra-regional actors:

\footnotetext{
'Regional exchange of experiences and expertise however, is going to play an increasing major role in future strategies for improvement. One reason is that Asean models of higher education are essentially non-Asean; they are French, Dutch, American, Spanish
} 
H.N. Feuer and A.-K. Hornidge

and English. [...] A second observation that may be validly made is that the roles these models play in their countries are different. Similarly, the context in which they have to operate differs. In using higher education for development purposes, experience within the region is necessary.'

These authors acknowledge that external influences are a fundamental part of existing ASEAN systems of education, but that they have co-evolved with each of these countries in different ways since colonization. As Robertson and Keeling (2008) observed, any 'territorialising strategies' of the EHEA that threaten retention of students and the ability of national university systems to deliver cultural content (i.e. art, literature, language, and philosophy), will be met with the kind of culturalist-regionalist reactions displayed above by the Cambodian and Thai delegates. This is a more general reflection of the concern about retaining the social purpose of national cultural institutions in the face of globalization (Currie and Subotzky 2000, 124). This becomes apparent in conference presentations and high-level meetings, in which the importance of cultural sensitivity in any 'ASEAN Education Community' is routinely reference; however, the extent to which current activities (such as quality assurance, 'harmonization', and foreign partnerships) can achieve a basis different than the neoliberal, competitive models imported from abroad is questionable. Navigating these waters as an economically-weaker ASEAN member (i.e. CLMV) requires more careful strategic engagement. The case of Cambodia presented below is suggestive of a few ways this can be implemented.

\section{Cambodia}

Like most countries in ASEAN, Cambodia experienced an explosion of private higher education institutes (HEI) when the demand for tertiary education began outstripping the capacity of public institutions in the mid-1990's. From a base of 10 in 1990, the number of HEIs grew to 97 by 2012 (Sen 2013). Bunlay Nith (2013b) describes the past international 


\section{H.N. Feuer and A.-K. Hornidge}

engagement in higher education in Cambodia as similar to the post-Paris Peace Accords

NGO boom, except private investment and intervention in education are still proceeding unabated, primarily in the context of ASEAN. Because more than $60 \%$ of students are now served by private institutions, it is important to understand their potential role in higher education reform and integration. David Ford (2006) notes that commentators of this process generally fall into two camps: the neoliberals ('unashamedly probusiness types') and the 'idealists', who focus on education quality and social justice. The moral fault line separating these two camps is centered on the issue of whether one believes that HE reform should be driven by the boom-and-bust of university models (a business approach) or should be incrementally improved through democratic regulation that achieves societal goals and competitiveness simultaneously. For those in the latter category, however, time may be running out as the deadline for ASEAN economic integration (in 2015) is rapidly approaching, which will draw the Cambodian HE sector out into more open and fierce competition with neighboring education systems.

This is an approach taken by Cambodian researchers Vichet Sen and Soveacha Ros (2013) of the Cambodia Development Resource Institute (CDRI), who acknowledge that debates about the ideals of HE will become subsidiary to adaptation imperatives after 2015. Feuer (2014) has argued that institutes of higher education which proactively manage the inevitable integration while applying their own distinct social policy are in a better position to muddle through the post-2015 era. Private institutes typically operate on a competitive basis, which assumes that prospective students (i.e. customers) know what the most useful and highest value-for-money courses will be. Evidence from Cambodia (C. Tan 2007) and across ASEAN noting high graduate unemployment contradicts this (World Bank 2012). Due to language lock-in and travel restrictions, many one-building Cambodian universities have gotten away with offering minimalist business and management programs (Locard and Ang 
H.N. Feuer and A.-K. Hornidge

2010). Faced with the international transparency of higher education integration, and increased mobility, many of these institutions will not survive economic integration. For Cambodian HEIs to survive and prosper in a context of higher education integration they will need to serve a broader focus by providing encouraging campus environments (see section 4 in Sam, Zain, and Jamil 2012) and extra-curricular engagement for developing soft skills (Heng 2014) as well as a wide-range of job-focused social science and natural science training. Here it is instructive to looking at the longest-running universities, or those that have co-evolved with the long-running international presence in Cambodia.

The Royal University of Phnom Penh has around 122 active memoranda of understanding (most of which have been renewed continuously since Cambodia opened up in 1991), signed mostly with foreign universities. Of that, 50 are from East Asia, 29 from the EU, 12 from North America, 28 from Southeast Asia, and 3 from Australia. The number is not as impressive as the measured and decisive way in which these MoUs were cultivated: balancing regional influence (increased autonomy), garnering financing for difficult-to-fund subjects (like architecture, history, sociology, archaeology), expanding laboratory capacity, and improving faculty exchange for capacity building. This can be compared to the hurried, supply-driven way in which Yangon University has drawn up partnerships, which we described above.

Another example of proactive negotiation comes from Meanchey University, a peripheral university in Banteay Meanchey province catering primarily to the children of de-mobilized Khmer Rouge soldiers. As a public university developed with private assistance, including Thai support on an intra-ASEAN basis, it also has inked partnerships with China, Vietnam, Korea and Israel for various programs that it needs. While the university is by no means competitive at the international level, it serves a unique social duty in the conflict resolution 


\section{H.N. Feuer and A.-K. Hornidge}

while providing employable skills, and negotiating its partnerships strategically (Seng 2013).

These cases depart from the typical narrative of the growth in private HEIs, which have contributed to problems of distribution and quality control (Chet 2006), and either not sought international partnerships or partner haphazardly with private businesses and anyone offering financing. Both academic and multilateral evaluations of these institutions have noted problems with accreditation and quality assurance and their poor track record in achieving social goals and graduate employment (Ford 2003; IIEP and UNESCO 2011). Because accreditation was undermined by a last-minute amendment placing it under central control at the Council of Ministers and not an independent body (Ford 2003), external evaluation is the only manner of objectively determining the quality of an institution (Ford 2006). In this case, higher education integration (perhaps through ASEAN) would help weed out diploma mills from serious institutes. In particular, assistance could be provided through Cambodia's collaboration on accreditation with the Malaysian Qualification Authority and the Philippines Accrediting Association of Schools, Colleges and Universities. In the short term, this might mean loss of domestic students, but in the long-term more sustainable HEIs.

The case of Cambodia demonstrates that higher education reform and integration can, under certain circumstances, (a) strengthen existing institutions and allow them to survive internationalization while maintaining autonomy, (b) discover and support institutions (like Meanchey University) that deliver important social impacts, and (c) expose diploma mills.

\section{Conclusion: Higher Education Discourse - International Domains, Local Arenas}

The higher education landscape in Southeast Asia, and its socio-historic embeddings illuminated here through Keller's sociology of knowledge approach to discourse, comprises many of the tensions and challenges that have, and are to some degree still being faced by, 
H.N. Feuer and A.-K. Hornidge

European nations under the Bologna Process. Here, the craving to compete in the realm of 'knowledge creation' and to establish internationally-recognized research and learning centers often conflicts with the goal of securing a tertiary education system directed by national ideals and social imaginaries of a better, more inclusive, future. In ASEAN, this is additionally complicated by the sheer diversity in higher education systems, economic strength and national culture, as well as the specter of ethnic discord and violence in some regions. Nevertheless, the discourse around improving higher education quality found in intra-regional events is already suffused with de-politicized tasks that draw ASEAN into the nexus of the dominant international education domains, namely quality assurance and standardization, harmonization, and international partnerships and exchange. In SKAD terms, it is these tasks that act as social and material resources for action, in this case towards depoliticizing the higher education integration discourse. While the EHEA, Australia and the USA use the above-depicted range of discursive, non-discursive and model practices (in Keller's conception) for embedding their systems of reference into these activities, our analysis of the discourse also points to the generalized awareness of the need for reflexively managing the mobilization of these social and material resources to respect and benefit Southeast Asia. In terms used by Hornidge (2014), this is to say that, in chasing the normative (harmonization, integration) and factual implementation (standardization, quality assurance) elements of global knowledge discourse, the impact of the hegemonic elements (i.e. educational monocultures) can be actively minimized.

As we have documented in this paper, the dominant dispositifs of discourse production center around the optimistic conceptual progression of 'integration' (i.e. the inevitability of globalization), building a 'knowledge society' (Western-oriented constellation of academic competition), and 'reform' (i.e. the social imaginary of a better future). The arena of higher education in ASEAN is (historically) populated by countries that variously prioritize certain 
H.N. Feuer and A.-K. Hornidge

discourses and domains that tendentially leverage certain discourses or have pre-existing structures of symbolic and practical power. The competitive atmosphere of higher education in ASEAN is increasingly defined by struggles to re-arrange the existing symbolic order in Southeast Asia, especially in light of the increasing assertiveness of the Bologna Process. The different domains are equipped differently to manage these processes. Bologna is highly centralized, ordered and transparent but the USA and Australia have, respectively, dominant model practices (i.e. templates for action) and regional embeddedness. These international actors strategically work with and defer to regional allies, some of which are themselves dominant domains regionally, such as Singapore and Malaysia. Achieving broader success in ASEAN means that both international and regional actors have to simultaneously tie the dominant discourse of internal (economic) integration and development to their practice of 'external' (higher education) integration while avoiding perceived contradictions to national sovereignty.

As we have documented in higher education forums in Southeast Asia, the strident regionalist-culturalist orientation of many countries makes 'winning ASEAN' more complicated than implementing programs that align the region's model practices (e.g. credit system, exchange programs, bilateral university cooperation) with those of a higher education domain. Long-term dispositifs, in the form of university consortia, standardization agencies, and historical trends in academic mobility are thereby re-cast as a continuation of an important type of international diplomacy (namely higher education 'integration') that appear to be natural parallels to globalization and economic integration. However, integration has proven to be a far more contentious process, balanced around dual processes of building strategic partnerships and defending sovereignty. Some of the economically more advanced ASEAN countries (like Singapore, and to some degree Malaysia) are already working to uncouple the Western integrationist and sovereignty-threatening components (here called 


\section{H.N. Feuer and A.-K. Hornidge}

(un-)intended power effects), while still pushing technical standards and student mobility. In turn, our analyses of Myanmar and Cambodia suggest that while the economically weaker countries have agency in proactively managing the dual pressure of international and regional integration, there is also the more opportunistic and incoherent race for the biggest piece of the pie. The case of Myanmar illustrates more prototypically the 'raw' manifestation of this battleground, with foreign institutes competing with each other to influence the form and content of the emergent university system. Another (un-)intended power effect of this is higher education reform that outwardly promotes a de-politicized ideal of integration linked to the inevitability of globalization (including the aspiration for so-called 'elite universities'), but that pays lip service to the sensitive social challenges facing each country.

There is, however, an important silver lining that addresses the question we posed at the beginning of this paper, namely the potential for individual countries to leverage or exploit the broader hegemonic battle over ASEAN higher integration to improve their institutes of higher education. For the majority of ASEAN member countries that do not have the negotiation power and room to maneuver of Singapore, the international 'competition' to shore up and expand the big higher education domains is at least 'diluting' the pre-existing power structures and discursive pre-eminence built up in Southeast Asia by Britain, Australia and the USA, providing more room for lesser players to more strategically pick-and-choose among various contenders. The fragmentation in quality assurance agencies worldwide challenges harmonization with any standard and reinforces the sense that there is not a zerosum game afoot between higher education domains. For example, the APQN boasts 46 members in 27 Asia-Pacific countries, INQAAHE ${ }^{12}$ has 189 member agencies in 80 countries (some overlapping), and even UNESCO and OECD provide their own 'Guidelines on Quality

\footnotetext{
${ }^{12}$ INQAAHE: International Network for Quality Assurance Agencies in Higher Education
} 
H.N. Feuer and A.-K. Hornidge

Provision in Cross-Border Higher Education'. This is also evidenced by the many consortia with cross-regional mandates. The International Network of Universities (INU) connects institutions from Australia, Japan, USA, Korea, South Africa, the EU and Indonesia. In this environment, higher education domains struggle to gain monopoly as there are many players and potential higher education systems (Stella and APQN 2008, 21). ASEAN member countries would be wise to similarly spread their risk and recognize their desirability in the new higher education world order.

\section{Acknowledgements}

Our gratitude goes to fellow research colleague Prof. Conrad Schetter for help with work preceding this, and to Dr. Eric Beerkens for comments on a draft of this paper. We also thank the Fritz Thyssen Foundation for their generous support to this research project, and recognize no outstanding conflicts of interest in the publication of these findings.

\section{References}

ACA. 2005. Perceptions of European Higher Education in Third Countries. Brussels: Academic Cooperation Association.

ACCESS. 2010. Strategies to Strengthen Collaboration in Higher Education between Europe and South East Asia. ACCESS White Papers. Academic Cooperation Europe-SouthEast Asia Support.

Adelman, Clifford. 2009. The Bologna Process for US Eyes: Re-Learning Higher Education in the Age of Convergence. Washington, D.C.: Institute for Higher Education Policy. http://files.eric.ed.gov/fulltext/ED504904.pdf.

Altbach, Philip G. 1973. Comparative Higher Education. 5. ERIC/Higher Education Research Report. Washington, D.C.: American Association for Higher Education. Altbach, Philip G, and Hans de Wit. 1995. "International Higher Education: America Abdicates Leadership." International Higher Education 1 (Spring): 10-11. Anonymous. 2013a. Personal Communication, Quality of Higher Education Workshop, Yangon, Myanmar. . 2013b. Personal Communication, International Conference on Educational Reform 2013, Siem Reap, Cambodia.

Beech, Jason. 2011. Global Panaceas, Local Realities: International Agencies and the Future of Education. Vol. 22. Comparative Studies Series. Frankfurt am Main: Peter Lang.

Beerkens, Eric. 2004. "Global Opportunities and Institutional Embededdness: Higher Education Consortia in Europe and Southeast Asia". PhD, Twente, Netherlands: University of Twente. 
H.N. Feuer and A.-K. Hornidge

2008. "University Policies for the Knowledge Society: Global Standardization, Local Reinvention." Perspectives on Global Development and Technology 7 (1): 1536.

2014. 40 Yeras of Internationalization in European Higher Education: Achievements and Challenges. 21. RIHE International Seminar Reports. Hiroshima University.

Boatcã, Manuela. 2012. "Catching Up with the (New) West: The German 'Excellence Initiative,' Area Studies, and the Re-Production of Inequality." Human Architecture: Journal of the Sociology of Self-Knowledge 10 (1): 4.

Brittingham, Barbara. 2003. "American Accreditation of Foreign Universities: Proceedwith Caution." International Higher Education 33: 14-15.

Carter, Susan, John Fazey, José Luis Gonzalez Geraldo, and Chris Trevitt. 2011. "The Doctorate of the Bologna Process Third Cycle: Mapping the Dimensions and Impact of the European Higher Education Area." Journal of Research in International Education 9 (3): 245-58.

Chapman, James W. 2013. "Educational Skills for the 21st Century: Global and ASEAN." In Proceedings Fo the 6th International Conference on Educational Reform (ICER 2013), XXXVI-LVII. Siem Reap, Cambodia.

Chet, Chealy. 2006. "Cambodia." In Higher Education in South-East Asia. Bangkok: United Nations Educational, Scientific and Cultural Organization.

Croché, Sarah, and Jean-Émile Charlier. 2012. "Normative Influence of the Bologna Process on French-Speaking African Universities." Globalisation, Societies and Education 10 (4): 457-72.

Currie, Jan, and George Subotzky. 2000. "Alternative Responses to Globalization from European and South African Universities." In Globalization and Education: Integration and Contestation across Cultures, edited by Nelly P. Stromquist and Karen Monkman, 123-48. New York: Rowman and Littlefield.

De Wit, Hans. 2002. Internationalization of Higher Education in the United States of America and Europe: A Historical, Comparative and Conceptual Analysis. Westport, Connecticut: Greenwood Press.

DEST. 2006. The Bologna Process and Australia: Next Steps. Canberra: Australian Government: Department of Education, Science and Training.

Donaghue, Gregory. 2008. "The Bologna Process and Australia: A Study of the Attractiveness, Diffusion and Rejection of a Global Reform Idea". Master of Higher Education, Oslo, Norway: University of Oslo. https://www.duo.uio.no/handle/10852/31045.

Douglass, John Aubrey. 2006. The Waning of America's Higher Education Advantage: International Competitors Are No Longer Number Two and Have Big Plans in the Global Economy. 09.06. Research \& Occasional Paper Series. Center for Studies in Higher Education. http://escholarship.org/uc/item/0qd517tj.pdf.

EUA, and CUIB. 2006. Asturias Declaration. Oviedo: European University Association and Consejo Universitario Iberoamericano.

http://www.eua.be/eua/jsp/en/upload/EUA_CUIB_Asturias_Declaration_210406.114 6834606320.pdf.

European Commission. 2001. Europe and Asia: A Strategic Framework for Enhanced Partnerships. COM(2001) 469. Brussels: European Commission. 2005a. Communication to the Spring European Council. Working Together for Growth and Jobs. A New Start for the Lisbon Strategy. COM 2005 (24). European Commission. 2005b. EU - Asia-Link Programme: Phase II Guideline for Applicants. Brussels: European Commission. 
H.N. Feuer and A.-K. Hornidge

Evers, Hans-Dieter, and Anna-Katharina Hornidge. 2007. "Knowledge Hubs along the Straits of Malacca." Asia Europe Journal 5 (3): 417-33.

Fahmi, Zita Mohd. 2013. "Higher Education - Key Quality Challenges". presented at the Quality of Higher Education Workshop, Yangon, Myanmar, February 8.

Farrar, Lara. 2013. "Myanmar's Educators Reach Out to the World." The New York Times, May 5, sec. World / Asia Pacific.

http://www.nytimes.com/2013/05/06/world/asia/Myanmar-educators-reach-out-tothe-world.html.

Feuer, Hart Nadav. 2014. "ASEAN Integration and Runaway Privatization in Cambodian Higher Education: Can Private Universities Train Students and Spur Social Growth?" In Chiang Mai, Thailand.

Feuer, Hart Nadav, Anna-Katharina Hornidge, and Conrad Schetter. 2013. Rebuilding Knowledge: Opportunities and Risks for Higher Education in Post-Conflict Regions. 121. ZEF Working Paper Series. Bonn, Germany: Center for Development Research.

Figueroa, Francis Espinoza. 2010. "The Bologna Process as a Hegemonic Tool of Normative Power Europe (NPE): The Case of Chilean and Mexican Higher Education." Globalisation, Societies and Education 8 (2): 247-56.

Ford, David. 2003. "Cambodian Accreditation: An Uncertain Beginning." International Higher Education 33: 12-14.

- 2006. "Cambodia--Growing Pains." International Higher Education 44: 10-11.

Giddens, Anthony. 1992. Die Konstitution Der Gesellschaft. Entwurf Einer Theorie Der Strukturierung. Frankfurt am Main: Campus.

Goodwin, Craufurd D., and Michael Nacht. 2009. Missing the Boat: The Failure to Internationalize American Higher Education. Cambridge University Press.

Hartmann, Eva. 2008. "Bologna Goes Global: A New Imperialism in the Making?" Globalisation, Societies and Education 6 (3): 207-20.

Heng, Kreng. 2014. "The Relationships between Student Engagement and the Academic Achievement of First-Year University Students in Cambodia." The Asia-Pacific Education Researcher 23 (2): 179-89.

Hornidge, Anna-Katharina. 2007. Knowledge Society. Vision \& Social Construction of Reality in Germany \& Singapore. Münster, Germany: Lit-Verlag. . 2010. "An Uncertain Future - Singapore's Search for a New Focal Point of Collective Identity and Its Drive towards 'Knowledge Society." Asian Journal of Social Sciences 38 (5): 785-818.

- 2011. "Creative Industries' - Economic Program and Boundary Concept." Journal of Southeast Asian Studies 42 (2): 253-79.

. 2013. “'Knowledge', 'Knowledge Society' \& 'Knowledge for Development'. Studying Discourses of Knowledge in an International Context." In Methodologie Und Praxis Der Wissenssoziologischen Diskursanalyse, Band 1: Interdisziplinäre Perspektiven, edited by Reiner Keller and Inga Truschkat, 297-424. Wiesbaden, Germany: Springer VS Verlag.

Huang, Futao. 2007. "Internationalization of Higher Education in the Developing and Emerging Countries: A Focus on Transnational Higher Education in Asia." Journal of Studies in International Education 11 (3-4): 421-32.

IIEP, and UNESCO. 2011. Education and Fragility in Cambodia. Education in Emergencies and Reconstruction. Paris: International Institute for Education Planning and the United Nations Education Scientific and Cultural Organization.

Iskandar, Ira. 2009. Higher Education in ASEAN. Working Papers. Singapore: EU Centre.

Ka Ho Mok. 2011. "Regional Responses to Globalization Challenges: The Assertion of Soft Power and Changing University Governance in Singapore, Hong Kong and 
H.N. Feuer and A.-K. Hornidge

Malaysia." In Handbook on Globalization and Higher Education, edited by Roger King, Simon Marginson, and Rajani Naidoo, 179-96. Cheltenham, UK: Edward Elgar.

Kanyajananiyot, Porntip. 2013. "Round Table Discussion: ASEAN Education". presented at the International Conference on Educational Reform 2013, Siem Reap, Cambodia, February 24.

Keller, Reiner. 2005. "Analysing Discourse. An Approach from the Sociology of Knowledge." Forum Qualitative Sozialforschung / Forum: Qualitative Social Research 6 (3): Article 32. . 2011a. "The Sociology of Knowledge Approach to Discourse (SKAD)." Human Studies 34: 43-65. . 2011b. Wissenssoziologische Diskursanalyse. Grundlegung Eines Forschungsprogramms. Wiesbaden, Germany: Springer VS Verlag. . 2013. Doing Discourse Research: An Introduction for Social Scientists. London: Sage Publications.

King, Kenneth. 2013. "Improvements of Higher Education Quality - Implementation". presented at the Quality of Higher Education Workshop, Yangon, Myanmar, February 8.

Kraas, Frauke. 2013. "Improvements of Higher Education Quality - Institutinal Level". presented at the Quality of Higher Education Workshop, Yangon, Myanmar, February 8.

Kuroda, Kazuo, Takako Yuki, and Kyuwon Kang. 2011. Cross-Border Higher Education for Regional Integration: Analysis of the JICA-RI Survey on Leading Universities in East Asia. 26. JICA Research Institute Working Papers. Tokyo: Japan International Cooperation Agency. http://repository.ri.jica.go.jp/dspace/handle/10685/50.

Lane, Jason E. 2011. "Importing Private Higher Education: International Branch Campuses." Journal of Comparative Policy Analysis: Research and Practice 13 (4): 367-81.

Locard, Henri, and Tha Leang Ang. 2010. "Higher Education in Cambodia and the Atypical Example of the History Department at RUPP 2." Canadian and International Education/Education Canadienne et Internationale 39 (1): 59-66.

Lugano, Nathalie. 2013. "Quality and Quality Assurance Framework in Europe: Policy Framework Implications". presented at the Quality of Higher Education Workshop, Yangon, Myanmar, February 8.

Maiworm, Friedhelm. 2006. Results of the Survey on Study Programmes Awarding Double, Multiple or Joint Degrees. Kassel, Germany: Gesellschaft für Empirische Studien bR. http://www.ehea.info/Uploads/Seminars/Berlin_results_survey.pdf.

Marginson, Simon. 2011. "Strategizing and Ordering the Global." In Handbook on Globalization and Higher Education, edited by Roger King, Simon Marginson, and Rajani Naidoo, 394-414. Edward Elgar Publishing.

Myo Mint. 2013. "Welcome Address". presented at the Quality of Higher Education Workshop, Yangon, Myanmar, February 8.

NAFSA. 2008. International Education: The Neglected Dimension of Public Diplomacy. New York: Association of International Educators. http://www.nafsa.org/Explore_International_Education/Advocacy_And_Public_Polic y/International_Education_The_Neglected_Dimension_of_Public_Diplomacy/. . 2014a. Globa Market Share of International Students - Top Host Countries. New York: Association of International Educators. http://www.nafsa.org/policy. 2014b. The Economic Benefit of International Students. New York: Association of International Educators. http://www.nafsa.org/_/File/_/eis2014/USA.pdf. 
H.N. Feuer and A.-K. Hornidge

Naidoo, Rajani. 2011. "Rethinking Development: Higher Education and the New Imperialism." In Handbook on Globalization and Higher Education, edited by Roger King, Simon Marginson, and Rajani Naidoo, 40-58. Cheltenham, UK: Edward Elgar. $\mathrm{http}$ ://books.google.de/books?id=i9S5FaP_oSsC\&printsec $=$ frontcover\#v $=$ onepage\&q $\& \mathrm{f}=$ false.

Nith, Bunlay. 2013a. "Round Table Discussion: ASEAN Education". presented at the International Conference on Educational Reform 2013, Siem Reap, Cambodia, February 24.

- 2013b. Personal Communication.

OECD. 2014. Education at a Glance 2014: Highlights. Paris: Organisation for Economic CoOperation and Development. http://www.oecd.org/edu/eag.htm.

Olds, Kris, and Susan Robertson. 2011. "Mapping the Expansion of Bologna Process Membership." Global Higher Ed. April 20. http://globalhighered.wordpress.com/2011/04/20/mapping-bologna-processmembership/.

Ricken, Norbert. 2006. Die Ordnung Der Bildung. Beiträge Zu Einer Genealogie Der Bildung. Wiesbaden, Germany: VS-Verlag.

Robertson, Susan. 2008. "Europe/Asia' Regionalism, Higher Education and the Production of World Order." Policy Futures in Education 6 (6): 718.

Robertson, Susan, and Ruth Keeling. 2008. "Stirring the Lions: Strategy and Tactics in Global Higher Education." Globalisation, Societies and Education 6 (3): 221-40.

Rogers, Rebecca, ed. 2011. An Introduction to Critical Discourse Research in Education. 2nd ed. London: Lawrence Erlbaum.

Sam, Rany, Ahmad Nurulazam Md Zain, and Hazri Jamil. 2012. "The National Strategies and Policies That Contribute toward the Enhancement of Educational Quality in Cambodian Higher Educational Institutions." In Bandung, Indonesia.

SEAMEO-RIHED. 2012. A Study on Quality Assurance Models in Southeast Asian Countries: Towards a Southeast Asian Quality Assurance Framework. Bangkok: Regional Centre for Higher Education and Development and the Southeast Asian Ministers of Education Organisation.

Selvaratnam, V., and S. Gopinathan. 1984. "Higher Education in Asean towards the Year 2000." Higher Education 13 (1): 67-83.

Sen, Vicheth. 2013. "Cambodia's Higher Education Structure and the Implications of the 2015 ASEAN Economic Community." In Annual Development Review 2012-2013, 24-32. Phnom Penh, Cambodia: Cambodia Development Resource Institute.

Sen, Vicheth, and Soveacha Ros. 2013. Anatomy of Higher Education Governance in Cambodia. 86. Working Paper Series. Phnom Penh, Cambodia: Cambodia Development Resource Institute.

Seng, Sary. 2013. Personal Communication.

- 2014. "Panel Presentation". presented at the Workshop on citizenship education and education for ASEAN-ness in ASEAN 10 countries, Nagoya, Japan, February 20.

Shahjahan, Riyad A., and Adrianna J. Kezar. 2013. "Beyond the 'National Container' Addressing Methodological Nationalism in Higher Education Research." Educational Researcher 42 (1): 20-29.

Slantcheva-Durst, S. 2010. "Chapter 1: Redefining Short-Cycle Higher Education Across Europe: The Challenges of Bologna." Community College Review 38 (2): 111-32.

Smith, Alan. 2010. Paper Commissioned for the EFA Global Monitoring Report 2011, The Hidden Crisis: Armed Conflict and Education. Paris: United Nations Educational, Scientific and Cultural Organization. 
H.N. Feuer and A.-K. Hornidge

Stella, Antony, and APQN. 2008. Quality Assurance Arrangements in Higher Education in the Broader Asia-Pacific Region. Brisbane, Australia: Asia-Pacific Quality Network.

Takayama, Keita. 2014. 'Global 'Diffusion,' Banal Nationalism, and the Politics of Policy Legitimation: A Genealogical Study of 'Zest for Living' in Japanese Education Policy Discourse." In National Policy-Making: Domestication of Global Trends, 129-46. Routledge Advances in Sociology. New York: Routledge.

Tan, Charlene. 2007. "Educational Reforms in Cambodia: Issues and Concerns." Education Research Policy and Practice 6: 15-24.

Tan, Kay Chuan. 2013. "Quality and Quality Assurance in the ASEAN Region". presented at the Quality of Higher Education Workshop, Yangon, Myanmar, February 8.

Times Higher Education. 2015. “The World University Rankings: 2014-2015.” February 13. http://www.timeshighereducation.co.uk/world-university-rankings/2014-15/worldranking.

UK Trade \& Investment Malaysia. 2013. "ASEAN Knowledge Partnership: Showcasing UK Transnational Education in Malaysia.” March 20.

https://www.gov.uk/government/world-location-news/asean-knowledge-partnershipshowcasing-uk-transnational-education-in-malaysia.

UNESCO. 2011. EFA Global Monitoring Report 2011 - The Hidden Crisis : Armed Conflict and Education. Paris: United Nations Educational, Scientific and Cultural Organization.

. 2013. "UNESCO and the Ministry of Education in Myanmar Jointly Initiate inDepth Analysis of Policy, Legislation and Decentralization under Education Sector Reform." August 29. http://www.unescobkk.org/news/article/unesco-and-theministry-of-education-in-myanmar-jointly-initiate-in-depth-analysis-of-policy-legisl/.

Verbik, Line, and Veronica Lasanowski. 2007. "International Student Mobility: Patterns and Trends." World Education News and Reviews 20 (10): 1-16.

WES. 2005. Understanding and Evaluating The "Bologna Bachelors Degree". New York: World Education Services.

Wilde, Marc. 2013. "ASEAN-QA: Lessons Learnt from QA Capacity Development Projects on Sub-Regional Level". presented at the Quality of Higher Education Workshop, Yangon, Myanmar, February 8.

Wilkins, Stephen, and Jeroen Huisman. 2012. "The International Branch Campus as Transnational Strategy in." Higher Education 64 (5): 627-45.

World Bank. 2000. Higher Education in Developing Countries: Peril and Promise. Washington, D.C.: World Bank.

$\mathrm{http}: / / \mathrm{www}$. worldbank.icebox.ingenta.com/content/wb/840.

- 2005. Reshaping the Future: Education and Post-Conflict Reconstruction. Washington, D.C.: World Bank.

—. 2012. Putting Higher Education to Work: Skills and Research for Growth in East Asia. Washington, D.C.: World Bank.

Wrana, Daniel. 2006. Das Subjekt Schreiben. Reflexive Praktiken Und Subjektivierung in Der Weiterbildung - Eine Diskursanalyse. Baltmannsweiler: Schneider Verlag Hohengehren.

Zgaga, Pavel. 2006. Looking out: The Bologna Process in a Global Setting. On the "External Dimension" of the Bologna Process. Oslo, Norway: Norwegian Ministry of Education and Research. http://www.seeeducoop.net/education_in/pdf/06\%20Bologna_Global_final_report.pdf. 